\title{
PENGARUH SCHOOL ENGAGEMENT, LOCUS OF CONTROL, DAN SOCIAL SUPPORT TERHADAP RESILIENSI AKADEMIK REMAJA
}

\author{
Ika Rahayu Satyaninrum \\ STAI Al-Hamidiyah Jakarta \\ ikarahayu86@gmail.com
}

\begin{abstract}
This study was conducted to measure school engagement, locus of control, and social support on teenagers' academic resilience. Number of sample of this study is 214 students aged 15-18 years old. Data was obtained through scale filling to measure academic resilience with adaptation of Academic Resilience Inventory scale, school engagement using adaptation of School Engagement Measure, locus of control using adaptation of The Internal-External Scale, and social support using adaptation of The Multidimensional Scale of Perceived Social Support. Data analysis used multiple regression analysis. The result of this study indicates that there is significant collective effect of school engagement, locus of control and social support on teenagers' academic resilience. Proportion of variance from teenagers' academic resilience which was explained by all independent variables was $9.8 \%$. Variable which shows the most dominant positive tendency and significantly affects teenagers' academic resilience are behavioral engagement and cognitive engagement.
\end{abstract}

Keywords: Academic Resilience, Social Support, School Engagement, Locus of Control

\begin{abstract}
Abstrak
Penelitian ini dilakukan untuk mengukur school engagement, locus of control, dan dukungan sosial terhadap resiliensi akademik remaja. Sampel penelitian berjumlah 214 siswa usia 15-18 tahun. Data diperoleh melalui pengisian skala, untuk mengukur resiliensi akademik, skala Academic Resilience Inventory diadaptasi, sedangkan pengukuran school engagement, skala School Engagement Measured diadaptasi, pengukuran locus of control, skala The Internal-External Scale diadaptasi, dan pengukuran dukungan sosial dalam penelitian ini skala The Multidimensional Scale of Perceived Social Support diadaptasi. Analisis data yang digunakan adalah analisis regresi berganda. Hasil penelitian menunjukkan bahwa ada pengaruh bersama yang signifikan dari school engagement, locus of control dan dukungan sosial terhadap resiliensi akademik remaja. Proporsi varians dari resiliensi akademik pada remaja yang dijelaskan oleh semua variabel independen adalah sebesar $9.8 \%$. Variabel yang menunjukkan kecenderungan positif paling dominan dan secara signifikan memengaruhi resiliensi akademik remaja adalah behavioral engagement dan cognitive engagement.
\end{abstract}

Kata Kunci: Resiliensi Akademik, Dukungan Sosial, School Engagement, Locus Of Control 


\section{PENDAHULUAN}

Pendidikan memiliki peran yang sangat penting dalam mempersiapkan siswa untuk menghadapi perubahan zaman. Dalam menjalankan proses pendidikan para siswa seringkali dihadapkan dengan berbagai macam permasalahan yang dapat menyulitkan siswa untuk berhasil di sekolah, permasalahan ini dapat disebabkan oleh berbagai faktor seperti tingginya tingkat kriminalitas, kemiskinan, angka putus sekolah, penyalahgunaan obat-obatan, kesehatan dan permasalahan sosial lainnya (Babbi \& Byrne; Jeffries; Schensul; Van Horn dalam Speight, 2009; Waxman, Gray \& Padron, 2003).

Seiring dengan perkembangan zaman maka permasalahan dalam dunia pendidikan pun semakin kompleks, hal ini tentunya menjadi tantangan bagi penyelenggaraan pendidikan di Indonesia mengingat pentingnya pendidikan bagi setiap manusia. Pendidikan tidak hanya sekadar mempersiapkan siswa untuk dapat menghadapi kehidupan saat ini tetapi juga dipersiapkan untuk kehidupan yang akan datang. Saat ini telah banyak penelitian yang menunjukkan pencapaian prestasi siswa dari berbagai negara, namun kenyataannya prestasi siswa Indonesia di dunia masih sangat rendah. Berdasarkan hasil studi dari TIMSS (Trends International in Mathematics and Science Study) yang dirilis atas pengujian terhadap para siswa di tahun 2011 terungkap bahwa nilai matematika siswa di Indonesia menempati urutan ke 38 dari 42 negara, sedangkan untuk sains menempati urutan ke 40 dari 42 negara (Martin dkk, 2012).

Dalam penelitian lainnya terungkap bahwa angka putus sekolah di Indonesia masih cukup tinggi, berdasarkan data dari Badan Pusat Statistik Republik Indonesia pada tahun 2011 menunjukkan rata-rata nasional angka putus sekolah untuk kelompok umur 7-12 tahun (jenjang SD) adalah 0,67\%. Untuk kelompok umur 13-15 tahun (jenjang SMP) adalah 2,21\% dan kelompok umur 16-18 tahun (jenjang SMA) adalah 3,14\%. Dari segi angkanya, secara nasional terdapat 182.773 siswa SD yang tidak tamat pendidikannya. Sedangkan untuk tingkat SMP terdapat 209.976 siswa yang putus sekolah, dan pada tingkat SMA sebanyak 223.676 siswa putus sekolah (Kemdikbud, 2013). Hal ini yang kemudian menyebabkan rendahnya Education Development Index (EDI) Indonesia di dunia yaitu menempati peringkat ke 64 dari 120 negara (UNESCO, 2012).

Berdasarkan fakta-fakta tersebut maka diperlukan berbagai cara untuk meningkatkan prestasi pendidikan Indonesia di dunia, misalnya dengan 
meningkatkan prestasi siswa. Salah satu bidang penelitian yang mempunyai implikasi penting untuk meningkatkan pendidikan bagi siswa yaitu berkaitan dengan resiliensi siswa, atau mereka yang berhasil di sekolah meskipun dengan kondisi yang kurang baik. Selama beberapa dekade terakhir, penelitian tentang resiliensi telah banyak dilakukan dalam mengembangkan bidang psikopatologi, psikologi, sosiologi dan antropologi (Waxman, Gray\&Padron, 2003).

Resiliensi di bidang pendidikan menyajikan sebuah kerangka kerja untuk memahami mengapa beberapa anak-anak yang beresiko dapat berhasil di sekolah, sedangkan yang lainnya tidak (Geste, 2010). Alva (dalam Waxman, Gray dan Padron, 2003) menggunakan istilah resiliensi akademik untuk menggambarkan siswa yang mampu mempertahankan tingkat prestasi yang tinggi, motivasi dan kinerja, meskipun dengan adanya peristiwa yang menekan dan kondisi yang menempatkan mereka pada resiko untuk melakukan hal buruk di sekolah dan terancam dikeluarkan dari sekolah.

Berdasarkan berbagai riset yang telah dilakukan oleh para peneliti, terdapat berbagai faktor yang mempengaruhi terbentuknya resiliensi akademik pada remaja usia sekolah atau disebut siswa. Siswa dapat menjadi resilien jika memiliki tempramen positif termasuk di dalamnya tingkat aktivitas tinggi dan respon positif terhadap orang lain, motivasi berprestasi, memperoleh dukungan yang tinggi dan hubungan sosial yang baik dari keluarga, guru dan teman sebaya, menikmati datang ke sekolah dan lebih terlibat dalam kegiatan sekolah, memiliki internal locus of control, berpandangan positif terhadap sekolah dan sistem pengajaran di sekolah, memiliki rasa persahabatan dan kekeluargaan, siswa yang resilien cenderung memiliki fungsi intelektual yang baik karena dapat melindungi siswa dalam menghadapi masalah dan berperilaku. Siswa yang demikian menjadi lebih termotivasi sehingga dapat meningkatkan resiliensi akademik yang berpengaruh terhadap prestasi siswa (Luthar, dkk, 2000; Fullarton, 2002; Alva; Gonzales\&Padilla; dalam Waxman, Gray\&Padron, 2003; Willms, 2003; Fredrick, dkk, 2004; Samuels, 2004; Cunningham, nn).

Resiliensi akademik didefinisikan sebagai kapasitas individu untuk beradaptasi dengan situasi akademik, dengan merespon secara sehat dan produktif untuk memperbaiki diri sehingga mampu menghadapi dan mengatasi tuntutan akademik. Sedangkan school engagement didefinisikan sebagai kemampuan siswa untuk dapat mengenali, memaknai, dan berpartisipasi dalam kegiatan sekolah. Locus of control didefinisikan sebagai 
kemampuan individu dalam merasakan hubungan antara usaha-usaha yang telah dilakukan dengan akibat-akibat yang diterimanya, yang meliputi internal locus of control yaitu perilaku seseorang dikontrol dan dikendalikan oleh faktor yang ada dalam dirinya sendiri atau eksternal locus of control yaitu perilaku seseorang dikontrol dan dikendalikan oleh faktor keberuntungan, nasib dan kesempatan. Social Support atau dukungan sosial adalah hadirnya seseorang yang dapat menunjukkan atau memberikan kasih sayang, perhatian, penghargaan atau bantuan kepada orang lain sehingga dapat meningkatkan kesejahteraan dan dapat meningkatkan ketahanan terhadap masalah. Adapun tujuan dari penelitian ini adalah untuk mengukur pengaruh school engagement, locus of control, dan social support terhadap resiliensi akademik remaja.

\section{METODE}

\section{Partisipan}

Partisipan penelitian adalah siswa-siswi Madrasah Aliyah Negeri (MAN) 11 Jakarta, yang berlokasi di Jakarta Selatan kelas X dan XI jurusan IPA dan IPS, berusia 15-18 tahun. Peneliti menyebarkan kuesioner sebanyak 224 buah dan kembali dalam jumlah yang sama, namun 10 kuesioner tidak dapat diolah karena tidak lengkap dalam mengisi jawaban sehingga hanya sebanyak 214 kuesioner yang dapat diolah datanya dan diikutsertakan dalam analisis data.

\section{Prosedur penelitian}

Pengambilan data sebanyak 224 siswa dilakukan selama satu hari, yaitu pada saat siswa selesai mengerjakan ujian akhir semester. Sebelum pengambilan data peneliti mengadakan rapat koordinasi dengan pihak sekolah, panitia ujian dan pengawas ujian. Dalam rapat koordinasi ini peneliti menjelaskan maksud dan tujuan penelitian serta menjelaskan petunjuk pengisian skala, hal ini diperlukan karena pengambilan data akan dilakukan sesaat setelah siswa selesai mengerjakan ujian akhir semester. Siswa dikondisikan masih berada di ruang ujian agar tetap kondusif kemudian diberikan pengarahan untuk mengisi skala oleh pengawas dan peneliti tetap memonitor kegiatan pengambilan data pada setiap ruangan. 


\section{Pengukuran}

Data demografi. Lembar identitas responden ini berisi data pribadi siswa yang meliputi data diri, data keluarga dan keadaan ekonomi keluarga.

Resiliensi akademik. Pengukuran resiliensi akademik dengan mengadaptasi skala Academic Resilience Inventory (ARI) yang dikembangkan oleh Samuels (2004). Instrument ini terdiri dari 40 item. Skala ini terdiri dari pernyataan self report yaitu pernyataan-pernyataan yang menempatkan individu pada situasi yang menggambarkan dirinya, pengukurannya dengan menggunakan skala Likert lima poin dari sangat tidak setuju sampai sangat setuju.

School engagement. Pengukuran school engagement dengan mengadaptasi skala School Engagement Measure (SEM) yang dikembangkan oleh Fredricks, dkk (dalam Moore \& Lippman, 2005). Skala ini terdiri dari 15 item dan mengukur beberapa dimensi, yaitu behavioral engagement meliputi mengerjakan tugas dan menaati peraturan; emotional engagement menggabungkan ketertarikan, nilai dan emosi, dan cognitive engagement meliputi motivasi, usaha dan penggunaan strategi. Skala ini terdiri dari pernyataan self report yaitu pernyataan-pernyataan yang menempatkan individu pada situasi yang menggambarkan dirinya, pengukurannya dengan menggunakan skala Likert lima poin dari tidak pernah sampai selalu.

Locus of control. Pengukuran locus of control dengan mengadaptasi skala The Internal-External (I-E) Scale yang dikembangkan oleh Rotter (1966) dengan 29 item pertanyaan. Penilaian untuk tiap item internal adalah 0 (nol) dan tiap item eksternal adalah 1 (satu). Rotter (1966) memasukkan 6 buah pertanyaan yang bersifat distractor untuk menghindari responden terpengaruh dengan pertanyaan sebelumnya, sehingga skor minimal untuk instrumen ini adalah 0 (extreme internal) dan maksimal 23 (extreme external). Semakin rendah skor responden artinya responden memiliki internal locus of control. Sedangkan semakin tinggi skor responden, maka responden memiliki external locus of control. Dalam penelitian ini digunakan 23 item pernyataan setelah dikurangi 6 item yang bersifat distractor. Skala locus of control, terdiri dari pernyataan self report yaitu pernyataan-pernyataan yang menempatkan individu pada situasi yang menggambarkan dirinya. Penilaiannya dengan memilih salah satu dari dua alternatif jawaban yaitu untuk tiap item internal bernilai 0 (nol) dan tiap item eksternal bernilai 1 (satu). 
Social support. Pengukuran social support dalam penelitian ini dengan mengadaptasi skala The Multidimensional Scale of Perceived Social Support (MSPSS) yang dikembangkan oleh Gregory D. Zimet pada tahun 1988 dan dalam perkembangannya MSPSS telah digunakan untuk mengukur perceived social support pada budaya yang berbeda-beda (Zimet, G.D\&Canty-Mitchell, 2000). MPSS terdiri dari 12 item pernyataan dan pengukurannya menggunakan skala Likert tujuh poin dari sangat tidak cocok sekali sampai sangat cocok sekali. Skala ini terdiri dari pernyataan self report yaitu pernyataan-pernyataan yang menempatkan individu pada situasi yang menggambarkan dirinya, pengukurannya dengan menggunakan skala Likert tujuh poin dari sangat tidak cocok sekali sampai sangat cocok sekali.

Dalam penelitian ini validitas konstruk dari setiap instrumen diuji dengan Confirmatory Factor Analysis (CFA). CFA digunakan untuk menguji sejauhmana masing-masing item valid di dalam mengukur apa yang ingin diukur. Dalam CFA peneliti yang berperan untuk menetapkan banyaknya faktor dan item serta keterkaitan diantara keduanya yaitu item mana yang dirancang untuk mengukur faktor yang mana. Dengan demikian CFA ini bertujuan untuk menguji hipotesis tentang satu atau lebih faktor serta saling keterkaitan antar faktor tersebut sesuai dengan model teori yang telah ditetapkan. CFA ini dianggap lebih scientific karena ada hipotesis tentang suatu model teoritis serta pengukurannya, yang dapat diuji kebenarannya secara empirik dengan menggunakan metoda statistika (Umar, 2013). Dalam penelitian ini yang diuji adalah sebuah model unidimensional (satu faktor) dan jika ternyata model ini fit dengan data maka dapat dilakukan uji hipotesis apakah masing-masing item signifikan di dalam mengukur apa yang ingin diukur. Untuk menguji hal ini peneliti menggunakan software Lisrel (Jöreskog \& Sörbom, 1999).

\section{Analisa Statistik}

Pendekatan yang digunakan dalam penelitian ini adalah pendekatan kuantitatif yang menekankan analisisnya pada data-data numerikal (angka) yang diolah dengan metode statistika. Kemudian dalam menguji hipotesis penelitian digunakan metode analisis regresi berganda (multiple regression analysis) yaitu suatu metode untuk meramalkan dan menguji signifikan tidaknya pengaruh dari sekumpulan variabel bebas (IV) terhadap satu variabel terikat (DV). Teknik analisis regresi berganda (multiple regression analysis) yang digunakan dalam penelitian ini bertujuan untuk mengetahui 
besarnya pengaruh dari ketujuh variabel bebas (IV) terhadap resiliensi akademik (DV).

\section{HASIL}

Sampel dalam penelitian ini berjumlah 214 orang siswa usia 15-18 tahun, selanjutnya karakteristik sampel dalam penelitian ini dijelaskan di tabel 1 .

\section{Tabel 1}

Karakteristik Sampel Penelitian

\begin{tabular}{|c|c|c|}
\hline \multicolumn{2}{|c|}{ Karakteristik } & $\begin{array}{l}\mathrm{N}=214 \\
\mathrm{n}(\%)\end{array}$ \\
\hline \multirow[t]{4}{*}{ Usia } & 15 tahun & $\begin{array}{ll}16 & (7.5)\end{array}$ \\
\hline & 16 tahun & $94 \quad(43.9)$ \\
\hline & 17 tahun & $77 \quad(36.0)$ \\
\hline & 18 tahun & $27 \quad(12.6)$ \\
\hline \multirow[t]{2}{*}{ Jenis Kelamin } & Laki-laki & $86 \quad(40.2)$ \\
\hline & Perempuan & $128(59.8)$ \\
\hline \multirow[t]{2}{*}{ Pekerjaan Ayah } & Bekerja & $214(100)$ \\
\hline & Tidak Bekerja & $0 \quad(0)$ \\
\hline \multirow[t]{2}{*}{ Pekerjaan Ibu } & Bekerja & $40 \quad(18.7)$ \\
\hline & Tidak Bekerja & $174(81.3)$ \\
\hline \multirow[t]{4}{*}{ Pendidikan Ayah } & $\mathrm{SD}$ & $11 \quad(5.1)$ \\
\hline & SMP & $15 \quad(7.0)$ \\
\hline & SMA & $111(51.9)$ \\
\hline & Perguruan Tinggi & $77 \quad(36.0)$ \\
\hline \multirow[t]{5}{*}{ Pendidikan Ibu } & $\mathrm{SD}$ & $(14.0)$ \\
\hline & SMP & $(18.7)$ \\
\hline & SMA & $(43.0)$ \\
\hline & Perguruan Tinggi & $(24.3)$ \\
\hline & $<$ Rp.2.200.000 & $(38.8)$ \\
\hline \multirow[t]{3}{*}{ Penghasilan Ayah } & Rp.2.200.000-Rp.3.300.000 & $(39.2)$ \\
\hline & $>$ Rp.3.300.000 & $(22.0)$ \\
\hline & $<$ Rp. 2.200 .000 & $185(86.4)$ \\
\hline \multirow[t]{2}{*}{ Penghasilan Ibu } & Rp.2.200.000-Rp.3.300.000 & $19 \quad(8.9)$ \\
\hline & >Rp.3.300.000 & $(4.7)$ \\
\hline
\end{tabular}

Dalam menguji hipotesis penelitian digunakan metode analisis regresi berganda. Dalam regresi ini akan dilihat apakah IV berpengaruh signifikan terhadap DV kemudian dilihat juga besaran $\mathrm{R}$ square untuk mengetahui berapa persen (\%) varians DV yang dijelaskan oleh IV, kemudian melihat signifikan atau tidaknya koefisien regresi dari masing-masing IV. 
Tabel 2

Nilai $R$ Square

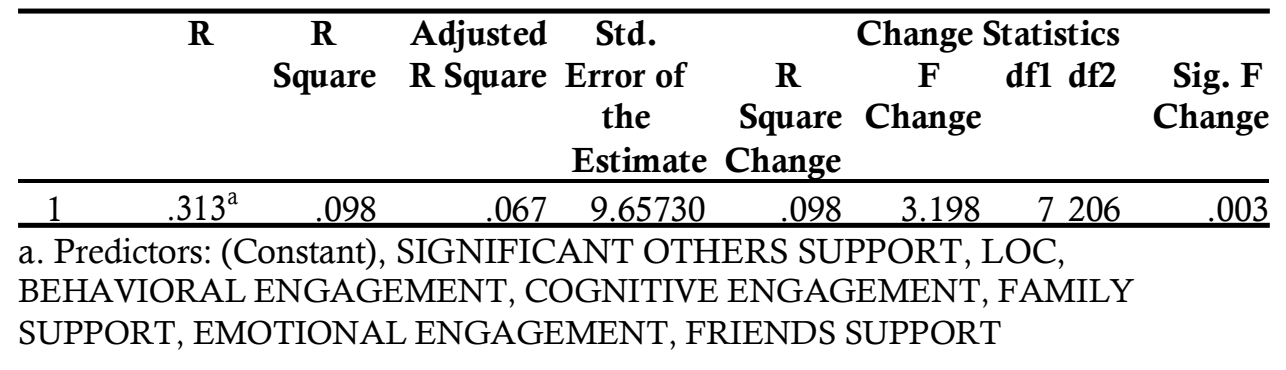

Dari tabel 2 di atas dapat diketahui bahwa perolehan nilai $\mathrm{R}$ square sebesar 0,098 atau sebesar 9,8\% dengan nilai $\mathrm{df} 1=7$ dan $\mathrm{df} 2=206$ sedangkan nilai $\mathrm{F}=3,198$ (pada taraf signifikansi 5\%). Nilai tersebut berarti sebesar $9,8 \%$ bervariasinya resiliensi akademik pada remaja dipengaruhi oleh semua IV dalam penelitian ini, sedangkan sisanya sebesar 90,2\% dipengaruhi oleh variabel lain di luar penelitian ini. Kemudian peneliti melakukan uji $\mathrm{F}$ untuk menganalisis pengaruh dari keseluruhan IV terhadap resiliensi akademik remaja. Adapun hasil uji $\mathrm{F}$ dapat dilihat pada tabel 2 berikut ini:

\section{Tabel 3}

ANOVA Pengaruh Keseluruhan IV terhadap DV

\begin{tabular}{|c|c|c|c|c|c|c|}
\hline \multicolumn{2}{|c|}{ Model } & \multirow{2}{*}{$\begin{array}{l}\begin{array}{l}\text { Sum of } \\
\text { Squares }\end{array} \\
2087.728\end{array}$} & \multirow{2}{*}{ Df } & \multirow{2}{*}{$\begin{array}{r}\text { Mean Square } \\
298.247\end{array}$} & \multirow{2}{*}{$\begin{array}{l}\mathbf{F} \\
3.198\end{array}$} & \multirow{2}{*}{$\begin{array}{l}\text { Sig. } \\
.003^{b}\end{array}$} \\
\hline & Regression & & & & & \\
\hline 1 & Residual & 19212.272 & 206 & 93.263 & & \\
\hline & Total & 21300.000 & 213 & & & \\
\hline
\end{tabular}

a. Dependent Variable: ACADEMIC RESILIENCE

b. Predictors: (Constant), SIGNIFICANT OTHERS SUPPORT, LOC, BEHAVIORAL ENGAGEMENT, COGNITIVE ENGAGEMENT, FAMILY SUPPORT, EMOTIONAL ENGAGEMENT, FRIENDS SUPPORT

Dari tabel di atas, diketahui bahwa nilai p (sig.) pada kolom paling kanan adalah sebesar 0,003 atau $p=0,003$. Dengan demikian diketahui bahwa nilai $\mathrm{p}<0,05$, maka hipotesis nihil yang menyatakan tidak ada pengaruh yang signifikan dari keseluruhan IV terhadap resiliensi akademik remaja ditolak, artinya, ada pengaruh yang signifikan dari school engagement, locus of control dan social support terhadap resiliensi akademik remaja.

Langkah selanjutnya adalah melihat koefisien regresi dari masingmasing IV. Untuk mengetahui signifikan atau tidaknya koefisien regresi 
yang dihasilkan, dapat dilihat melalui kolom nilai t (kolom ke-5) ataupun kolom nilai sig. (kolom ke-6). Jika $t>1,96$ atau sig $<0,05$ maka koefisien regresi yang dihasilkan signifikan pengaruhnya terhadap resiliensi akademik remaja, begitupun sebaliknya. Adapun besarnya koefisien regresi dari masing-masing IV terhadap resiliensi akademik dapat dilihat pada tabel 4 berikut ini:

\section{Tabel 4}

Koefisien Regresi

\begin{tabular}{|c|c|c|c|c|c|}
\hline \multirow[t]{2}{*}{ Model } & \multicolumn{2}{|c|}{$\begin{array}{l}\text { Unstandardized } \\
\text { Coefficients }\end{array}$} & \multirow{2}{*}{$\begin{array}{c}\text { Standardized } \\
\text { Coefficients } \\
\text { Beta }\end{array}$} & \multirow[t]{2}{*}{$\mathbf{t}$} & \multirow[t]{2}{*}{ Sig. } \\
\hline & B & $\begin{array}{l}\text { Std. } \\
\text { Error }\end{array}$ & & & \\
\hline 1 (Constant) & 25.551 & 8.739 & & 2.924 & .004 \\
\hline $\begin{array}{l}\text { BEHAVIORAL } \\
\text { FNGAGFMFNT }\end{array}$ & .214 & .102 & .155 & 2.112 & .036 \\
\hline EMOTIONAL & .027 & .085 & .024 & 320 & 749 \\
\hline ENGAGEMENT & & & & & \\
\hline $\begin{array}{l}\text { COGNITIVE } \\
\text { ENGAGEMENT }\end{array}$ & .156 & .078 & .142 & 1.985 & .049 \\
\hline LOCUS OF CONTROL & -.078 & .091 & -.058 & -.855 & .393 \\
\hline FAMILY SUPPORT & .112 & .083 & .102 & 1.344 & 180 \\
\hline FRIENDS SUPPORT & .011 & .104 & .009 & .109 & .913 \\
\hline $\begin{array}{l}\text { SIGNIFICANT OTHERS } \\
\text { SUPPORT }\end{array}$ & .046 & .087 & .043 & .534 & .594 \\
\hline
\end{tabular}

a. Dependent Variable: ACADEMIC RESILIENCE, sig $<0.05$

Berdasarkan tabel 4 koefisien regresi di atas, terdapat dua IV yang berpengaruh signifikan terhadap DV yaitu:

1. Variabel behavioral engagement

Pada tabel diperoleh koefisien regresi sebesar 0,214 dengan nilai $t=2,112$ $(t>1,96)$ dan nilai $p=0,036(p<0,05)$, karena nilai $t>1,96$ dan nilai $p<0,05$ maka Ha yang berbunyi "terdapat pengaruh yang signifikan dari behavioral engagement terhadap resiliensi akademik siswa" diterima.

Sehingga dapat disimpulkan bahwa behavioral engagement memiliki pengaruh yang positif dan signifikan terhadap resiliensi akademik siswa. Hal ini berarti bahwa semakin tinggi behavioral engagement, maka semakin tinggi resiliensi akademik dan signifikan secara statistik.

2. Variabel cognitive engagement

Pada tabel diperoleh koefisien regresi sebesar 0,156 dengan nilai $t=1,985$ $(t>1,96)$ dan nilai $p=0,049(p<0,05)$, karena nilai $t>1,96$ dan nilai $p<0,05$ 
maka Ha yang berbunyi "terdapat pengaruh yang signifikan dari cognitive engagement terhadap resiliensi akademik siswa" diterima. Sehingga dapat disimpulkan bahwa cognitive engagement memiliki pengaruh yang positif dan signifikan terhadap resiliensi akademik siswa. Hal ini berarti bahwa semakin tinggi cognitive engagement, maka semakin tinggi resiliensi akademik dan signifikan secara statistik.

Untuk melihat perbandingan besar kecilnya pengaruh antara tiap IV terhadap DV dapat diketahui dengan dua cara, yaitu melihat nilai signifikansinya dan melihat standardized coefficients. Maka dari tabel diatas dapat diketahui perbandingan atau urutan IV yang memiliki pengaruh terbesar adalah sebagai berikut:

\section{Tabel 5}

Urutan IV Yang Memiliki Pengaruh terhadap DV Dari Terbesar Ke Terkecil

\begin{tabular}{llc}
\hline No & \multicolumn{1}{c}{ Independent Variable } & $\begin{array}{c}\text { Standardized Coefficients } \\
\text { (Beta) }\end{array}$ \\
\hline 1 & Behavioral engagement & 0.155 \\
2 & Cognitive engagement & 0.142 \\
3 & Family support & 0.102 \\
4 & Significant others support & 0.043 \\
5 & Emotional engagement & 0.024 \\
6 & Friends support & 0.009 \\
7 & Locus of Control & -0.058 \\
\hline
\end{tabular}

Sebagai kesimpulan dari tujuh IV yang diteliti, yaitu school engagement (behavioral, emotional, dan cognitive), locus of control, dan social support (family, friends, dan significant others) berdasarkan pertambahan $\mathrm{R}^{2}$ yang dihasilkan dari setiap penambahan IV yang dilakukan (sumbangan proporsi varians yang diberikan) hanya variabel behavioral engagement dan cognitive engagement yang memiliki pengaruh signifikan terhadap resiliensi akademik siswa. Sedangkan lima variabel lainnya tidak memiliki pengaruh yang signifikan terhadap resiliensi akademik siswa.

\section{DISKUSI}

Dari hasil penelitian ini, ditemukan bahwa terdapat beberapa faktor psikologis yang dinilai berpengaruh terhadap resiliensi akademik remaja. School engagement, locus of control dan social support memiliki pengaruh 
bersama yang signifikan terhadap resiliensi akademik remaja meskipun pengaruhnya kecil. Beberapa kemungkinan yang menyebabkan kecilnya pengaruh tersebut adalah adanya variabel lain yang mempengaruhi resiliensi akademik remaja seperti jenis kelamin, kondisi fisik dan kesehatan, interaksi dengan guru dan teman sebaya, keterampilan sosial, latar belakang keluarga, status sosial ekonomi orangtua, motivasi berprestasi, future orientations dan yang tidak diteliti dalam penelitian ini.

School engagement berpengaruh positif terhadap resiliensi akademik remaja. Pengaruh positif yang paling dominan dan secara signifikan mempengaruhi resiliensi akademik remaja adalah behavioral engagement. Artinya keterlibatan remaja di sekolah dalam bentuk nyata yang meliputi partisipasi dalam kegiatan-kegiatan sekolah, terlibat dalam kegiatan akademik dan tugas-tugas belajar, berperilaku positif dan taat pada peraturan sekolah berpengaruh positif dan signifikan terhadap resiliensi akademik remaja. Papalia, Olds dan Feldman (2009) mendukung hasil penelitian ini dengan menyatakan bahwa faktor yang paling penting dalam membuat remaja untuk tetap bersekolah adalah active engagement atau keterlibatan dalam bentuk perilaku secara aktif yaitu sejauh mana siswa secara pribadi terlibat di sekolah. Karena salah satu faktor resiliensi yang penting dalam kehidupan remaja saat ini adalah keterlibatan mereka dengan sekolah atau engagement with school, apabila siswa kurang terlibat dalam kegiatan sekolah dipandang sebagai penyebab awal siswa putus sekolah (Fredricks, 2004). Dalam tingkat yang paling mendasar, active engagement meliputi masuk kelas tepat waktu, mempersiapkan diri, mendengarkan dan berespon terhadap guru, dan menaati peraturan sekolah. Kemudian pada tingkat berikutnya siswa dapat melibatkan diri dengan tugas-tugas sekolah, mengajukan pertanyaan, mengambil inisiatif untuk mencari bantuan saat dibutuhkan atau mengerjakan tugas tambahan.

Dalam penelitian ini juga terungkap bahwa cognitive engagement berpengaruh positif secara signifikan terhadap resiliensi akademik remaja. Artinya keterlibatan siswa secara kognitif yaitu meliputi kemampuan dalam belajar dan kemauan untuk melampaui persyaratan dasar untuk menguasai keterampilan yang sulit berpengaruh signifikan terhadap resiliensi akademik remaja. Hasil ini sejalan dengan penelitian yang mengungkap bahwa terdapat hubungan yang kuat antara cognitive engagement dengan prestasi siswa, misalnya dengan melihat nilai akademis yang telah dirancang untuk mengukur pemahaman siswa (Fredricks, dkk, 2004). Ditambahkan pula bahwa cognitive engagement adalah faktor bawaan yang ada dalam tiap 
individu yang dapat ditingkatkan melalui motivasi belajar dan self-regulated learning para siswa, dimana siswa yang memiliki cognitive engagement tinggi cenderung belajar secara teratur bukan hanya untuk mendapatkan nilai yang bagus.

Dalam penelitian ini juga ditemukan bahwa emotional engagement berpengaruh positif namun tidak secara signifikan terhadap resiliensi akademik siswa. Artinya keterlibatan siswa secara emosi yaitu meliputi reaksi afeksi baik positif dan negatif terhadap guru, teman sekelas, akademisi atau sekolah, termasuk juga identifikasi dengan sekolah yang mencakup belonging atau perasaan menjadi bagian terpenting dan bernilai bagi sekolah memiliki pengaruh positif terhadap resiliensi akademik siswa meskipun tidak secara signifikan. Sejalan dengan penelitian Gonzales dan Padilla (dalam Anne K. Driscoll, nn) yang mengungkapkan bahwa siswa yang merasa nyaman di sekolah memiliki hasil yang positif dibandingkan mereka yang merasa tidak menjadi bagian dari sekolah tersebut. Siswa dengan nilai yang tinggi memiliki sense of belonging yang besar daripada siswa yang tinggal kelas. Hasil penelitian ini juga sejalan dengan hasil survey yang menunjukkan bahwa hal yang berpengaruh positif terhadap school engagement yaitu meliputi perasaaan mereka untuk berprestasi dengan baik, memiliki guru yang dapat diajak berdiskusi, berpartisipasi aktif dalam kelompok olahraga di sekolah dan kegiatan-kegiatan lainnya (Taylor \& Nelms, 2006).

Siswa yang resilien cenderung untuk melakukan segala hal dengan baik di sekolah. Keberhasilan akademik tidak hanya menjadi hasil dari resiliensi, tetapi juga mempengaruhi kesukesan hidup di masa depan (Samuels, 2004). Hasil penelitian menunjukkan bahwa school engagement memberikan pengaruh terbesar terhadap resiliensi akademik remaja, karena siswa yang lebih terhubung dengan sekolahnya menjadi lebih termotivasi untuk berprestasi dan memperoleh pencapaian akademik yang lebih tinggi. Harga diri siswa dapat tumbuh dengan baik di sekolah apabila siswa merasa bahwa mereka menjadi bagian terpenting dan secara pribadi dihargai dan diakui menjadi bagian dari kelompok tersebut. Adanya keterlibatan aktif terhadap kegiatan sekolah, pandangan yang positif terhadap sekolah, rasa memiliki persahabatan (peer belonging), rasa kekeluargaan (familism) dan rasa memiliki terhadap sekolah (school belonging) menjadi prediktor yang signifikan terhadap resiliensi akademik.

Social support berpengaruh positif terhadap resiliensi akademik remaja, tetapi pada ketiga aspeknya tidak diperoleh pengaruh yang signifikan. 
Artinya dukungan keluarga, teman dan seseorang yang spesial memiliki pengaruh positif terhadap resiliensi akademik siswa meskipun tidak secara signifikan. Hal ini sejalan dengan penelitian dari CRESPAR (The Center for Research on the Education of Students Placed at Risk) yang meneliti pengaruh sumber daya sosial seperti orangtua, teman, guru dan dukungan sekolah terhadap resiliensi siswa. Ditemukan bahwa sumber daya sosial seperti orangtua yang peduli, partisipasi dalam kegiatan ekstrakulikuler dan guru yang mendukung siswa sangat bermanfaat dalam pencapaian prestasi akademik siswa (Nettles, Mucherach dan Jones, 2000). Pendapat hampir serupa diungkap Williams (2011) hasil penelitiannya menunjukkan bahwa hubungan antara keluarga, sekolah dan masyarakat dapat mendukung hasil akademik siswa menjadi lebih baik. Resiliensi dapat dijadikan penentu emosi yang positif, jika seseorang itu resilien maka dapat dijadikan indikator yang sangat kuat bahwa orang tersebut juga memiliki interaksi sosial yang positif (Homa, 2012).

Hal ini sejalan dengan teori ekologi yang menekankan bahwa seorang anak merupakan bagian yang integral dari lingkungan dimana ia berada. Brofenbrener (dalam Santrock, 2002) seorang pencetus teori ekologi menyatakan bahwa lingkungan sosiokultural seorang anak sangat mempengaruhi perkembangannya. Lingkungan ini dimulai dari lingkungan yang sangat dekat dengannya yaitu hubungannya dengan keluarga, kemudian meluas pada teman sebaya, sekolah dan masyarakat.

Hasil penelitian ini juga menunjukkan arah pengaruh yang negatif namun tidak signifikan yaitu pada variabel locus of control terhadap resiliensi akademik siswa. Artinya semakin tinggi locus of control atau seseorang dengan eksternal locus of control memiliki resiliensi akademik yang rendah, sedangkan semakin rendah locus of control atau seseorang dengan internal locus of control memiliki resiliensi akademik yang tinggi meskipun tidak secara signifikan. Hal ini sejalan dengan penelitian dari beberapa peneliti yang menyatakan bahwa anak-anak dan remaja yang resilien memiliki internal locus of control yang lebih besar dibandingkan anak-anak seusia mereka yang tidak resilien (Cowen, dkk; Grossman, dkk; Luthar\&Zigler; Magnus, dkk; Weist, dkk; Werner\&Smith , dalam Gizir, 2004). Sebagai contoh, internal locus of control secara positif dapat memprediksi prestasi akademik pada siswa sekolah menengah dan tinggi (Connell, Spencer\&Aber; Steveson, Chen\&Lee, dalam Gizir, 2004). Hasil penelitian ini juga sejalan dengan penelitian Gizir (2004) yang menunjukkan bahwa terdapat hubungan yang positif antara internal locus of control dengan 
resiliensi akademik siswa. Dengan memiliki internal locus of control seorang individu yakin bahwa peristiwa yang terjadi dalam hidup mereka merupakan hasil dari usaha dan tindakan mereka sendiri bukan keberuntungan. Dengan kata lain individu merasa yakin bahwa apa yang terjadi pada seseorang berada di bawah kendalinya. Hal ini diperkuat dengan penelitian Anne K. Driscoll (nn) bahwa individu dengan internal locus of control, yaitu orang yang percaya bahwa mereka memiliki kendali atas hidup mereka, lebih mungkin untuk dapat mengatasi kesulitan dan menunjukkan perkembangan yang sehat dan positif hasil daripada remaja yang percaya bahwa nasib mereka sebagian besar dikendalikan oleh pihak luar (eksternal locus of control).

Untuk penelitian lebih lanjut diharapkan dapat meninjau faktor-faktor lain yang berpengaruh terhadap resiliensi akademik remaja seperti jenis kelamin, kondisi fisik dan kesehatan, interaksi dengan guru dan teman sebaya, keterampilan sosial, latar belakang keluarga, status sosial ekonomi orangtua, motivasi berprestasi, future orientations dan hal lain yang tidak diteliti dalam penelitian ini sehingga dapat memperkaya hasil penelitian. Kemudian untuk memperdalam hasil penelitian, diharapkan dapat mengembangkan alat ukur yang sesuai dengan tahapan perkembangan dan lingkungan sosial budaya dari populasi penelitian mengingat masih terbatasnya alat ukur resiliensi akademik.

\section{DAFTAR PUSTAKA}

Ali, M \& Asrori, M. (2005). Psikologi remaja: Perkembangan peserta didik. Jakarta: Bumi Aksara.

Alva, S.A \& Padilla, A.M. (1995). Academic invulnerability among mexican american: a conceptual framework. The Journal of Educational Issue of Language Minority Students, 15. Boise State University.

Appleton, J., Betts, J.E., Reschly, A.L., Christenson, S.L \& Huebner, E.S. (2010). A study of the factorial invariance of school engagement instrument (SEI): Result from middle\&high school students. Journal of school psychology quarterly, 25(2), 84-93.

Benard, B. (1991). Fostering resiliency in kids: protective factors in the family, school, and community. San Fancisco: Far West Laboratory for Educational Research and Development.

Benard, B. (1995). Fostering resilience in children. Children Research Center. University of Illinois at Urbana Champaign.

Diunduh dari http://resilnet.uiuc.edu/library/benard95.html 
California Healthy Kids Survey. (2008). Resilience and youth development. Research Report. California Departement of Education.

Cunningham, E.G.W., Wei C. \& Bishop, N. (nn). Challanges to students engagement and school effectiveness indicators. Journal. Victoria: Swinburne University of Technology.

Demaray, M.K., Malecki, C.K., Jenkins, L.N. \& Cunningham, C.M. (2010). Chapter eight: Social support: how to assess and include it in research on prevention and youth outcomes. Dalam B. Doll, W. Pfhol \& J. Yoon (Eds.) Handbook of youth and prevention science. New York: Taylor\&Francais e-library.

Desmita. (2005). Psikologi perkembangan. Bandung: Remaja Rosdakarya.

Du Toit, M., \& Du Toit, S.H.C. (2001). Interactive LISREL user"s guide. Linclonwood, IL: Scientific Software International, Inc.

Driscoll, A. K. (nn). Academic resilience among low SES high school students. Journal. Davis: University of California.

Effendy, N. (1998). Dasar-Dasar Keperawatan Kesehatan Masyarakat. Jakarta: EGC.

Finn, J.D. (1989). Withdrawing from school. Review of Educational Research, 59(2), 117-142. Diunduh dari: http://rer.sagepub.com/content/59/2/117

Finn, J.D. (1993). Student engagement and students at risk. Washington, DC: National Center of Education Statistic.

Fredricks, J.A., Blumenfeld, P., \& Paris, A. (2004). School engagement: Potential of the concept, state of the evidence. Review of Educational Research, 74 (1), 59-109.

Fredricks, J.A., Blumenfeld, P., Friedel, J. \& Paris, A. (2005). Chapter 19: School engegaement. Dalam K.A. Moore \& L.H. Lippman (Eds.). What do children need to flourish?:conceptualizing and measuring indicators of positive development (305-321). New York: Springer.

Fredricks, J., McColskey, W., Meli, J., Mordica, J., Montrosse, B., \& Mooney, K. (2011). Measuring student engagement in upper elementary through high school: a description of 21 instruments. (Issues \& Answers Report, REL 2011-No. 098). Wash-ington, DC: U.S. Department of Education, Institute of Education Sciences, National Center for Education Evaluation and Regional Assistance, Regional Educational Laboratory Southeast. Diunduh dari http://ies.ed.gov/ncee/edlabs

Fullarton, Sue. (2002). Student engagement with school: Individual and school-level influence. Journal. Australian Council for Educational Research.

Geste, A. J. (2010). Urban elementary teachers" negotiation of school culture and the fostering of educational resilience. Doctoral Dissertation. The University of North Carolina at Charlotte. 
Giligan, R. (2000). Adversity, resilience and young people: the protective value of positive school and spare time experience. Children and Society, 14(1), 37-47.

Gizir, C. A. (2004). Academic resilience: an investigation of protective factors contributing to the academic achievement of eighth grade students in poverty. Doctoral Dissertation. The Graduate School of Social Science of Middle East Technical University.

Grothberg, E. H. (1999). Tapping your inner strength. Oakland, CA: New Harbinger Publications, Inc.

Grothberg, E. H. (1995). A guide to promoting resilience in children: Strengthening the human spirit. The International Resilience Project. Bernard van Leer Foundation. Diunduh dari: http://resilnet.uiuc.edu/library/grotb95b.html

Goodenow, C. (1993). The psychological sense of school membership among adolescents: Scale development and educational correlates. Journal Psychology in the Schools, 30, 79-90.

Goodenow, C., \& Grady, K. E. (1993). The relationship of school belonging and friends" value to academic motivation among urban adolescent students. The Journals of Experimental Education, 62 (1), 60-71.

Hampton, A. E. (2005). Locus of control and procrastination. Journal of epistimi. Diunduh dari: http://www.capital.edu/uploadedFiles/Capital/Academics/Services and_Programs/Undergraduate_Research/Epistimi/Content/Locus\% 20of\%20Control $\% 20$ and $\% 20$ Procrastination.pdf

Hill, R. \& Halpert, R. (2011) The locus of control contruct"s various means of measurement: a researcher"s guide to some of the more commonly used locus of control scale. Beach Haven NJ: Will to Power Press.

Homa, K. (2012). The effect of social support on resilience. Master Thesis. Kean University.

Hurlock, E.B. (1980). Development pychology a live-span approach. New York: McGraw-Hill, Inc.

Hetherington, E.M. \& Parke, R.D. (1999). Child Development: a Contemporary viewpoint. Singapore. Mc Graw Hill.

Johnson, D.W. \& Jhonson, F.P. (1991). Joining Together: Group Theory and Group Skills. Fourth Edition. London: Prentice Hall International.

Jöreskog, K.G \& Sörbom, D. (1999). Lisrel 8.7 for windows [computer software]. Linclonwood, IL: Scientific Software International, Inc.

Kapikiran, S. (2012). Validity and reliability of the academic resilience scale in turkish high school. Journal of Education, 132 (3), 474.

Kementerian Pendidikan dan Kebudayaan Republik Indonesia. (2013). Rembuk Nasional Pendidikan Dan Kebudayaan 2013: Menuntaskan Program Prioritas Pendidikan Dan Kebudayaan 2013-2014. Materi simposium.

Diunduh

dari: 
http://setjen.kemdikbud.go.id/pustekkom/wp-

content/uploads/downloads/2013/02/ 2013-Rembuknas-Arahan-

Mendikbud.pdf

Klohnen, E.C. (1996). Conceptual analysis and measurement of the construct of ego-resiliency. Journal of Personality and Social Psychology, 70 (5), 1067-1079.

Kutanis, R.O., Mesci, M., \& Ovdur, Z. (2011). The effect of locus of control on learning performance: A case of an academic organization. Journal of Economic and Social Studies, 2 (1).

Kwang, S.P \& Tang, Samuel. (2011). Singapore youth resilience survey: Examining the stressors, risks and resilience of young people. Research Report. Beyond Social Services.

Lakey, B., \& Cohen, S. (2000). Part two: Social support theory and measurement. Dalam S. Cohen, L.G. Underwood \& B.H. Gottlieb (Eds.). Social support measurement and intervention: a guide for health and social scientists (29-52). New York: Oxford University Press.

Larsen, R.J. \& Bush, D.M. (2002). Personality Psychology: Domains of Knowledge about Human Nature. New York: The McGraw-Hill

Levenson, H. (1981). Differentiating among internality, powerful others, and chance. Dalam H. Lefcourt (Eds.). Research with the Locus of Control Construct (15-63). New York: Academic Press.

Lopez, M.L \& Cooper, L. (2011). Social support measuring review. . Research Report. Los Angeles: Natinal Center for Latino Child and Family Research.

Luthar, S.S. (2000). Resilience and vulnerability: Adaptation in the context of childhood adversities. UK: Cambridge University Press.

Maddi, S.R. \& Khoshaba, D.M. (2005). Resilience at work: How to succeed no matter what life throws at you. New York: American Management Association.

Martin, A.J. \& Marsh, H.W. (2003). Academic resilience and the four cs: Confidence, control, composure and commitment. Journal. Australia: University of Western Sydney.

Martin, A.J. \& Marsh, H.W. (2006). Academic resilience and its psychological and educational correlates: a construct validity approach. Journal psychology in the school, 43 (3), 267-281.

Martin, M.O., Mullis, I.V.S., Foy, P., \& Stanco, G.M. (2012). TIMSS 2011 International result in science. Research Report. Amsterdam: International Association for the Evaluation of Educational Achievement (IEA).

Mash, E.J. \& Wolfe, D.A. (2010). Abnormal Child Psychology $4^{\text {th }}$ edition. USA: Wadsworth, Cengage Learning

Monks, F.J., Knoers, A.M.P. \& Haditono, S.R. (2000). Psikologi perkembangan: Pengantar dalam berbagai bagiannya. Yogyakarta: Gajah Mada University Press. 
Nowicki, S.Jr. \& Strickland, B.R. (1973). A locus of control scale for children. Journal of consulting and clinical psychology, 40 (1), 148-154.

Orford, J. 1992. Community Psychology: Theory and Practical. New York: John Wiley and Sons, Ltd.

Papalia, D.E., Olds, S.W \& Feldman, R.D. (2001). Human development. New York: McGraw Hill.

Pedhazur, E.J. (1997). Multiple regression in behavioral research: explanation and prediction $3^{\text {rd }}$ edition. USA: Thomson Learning.

Peters, R.D. (2005). Chapter ten: A community-based approach to promoting resilience in young children, their families and their neighborhoods. Dalam R.D Peters, B. Leadbeater \& R.J. McMahon (Eds.). Resilience in children, families and community: Linking context to Practice and Policy (157-176). New York: Kluwer Academic/Plenum Publisher.

Reeve, J.M, Jang, H., Carrel, D., Jeon, S., \& Barch, J. (2004). Enhancing Students" Engagement by Increasing Teachers" Autonomy Support. Journal Motivation and Emotion, 28 (2),147-169.

Rotter, J.B. (1966). Generalized expectancies for internal versus external control of reinforcement. Psychological Monographs: General and Applied, 80 (1)

Rotter, J.B. (1990). The internal versus external control of reinforcement. Journal of American Psychologist, 45 (4), 489-493.

Samuels, W.E. (2004). Development of a non-intellective measure of academic success: toward the quantification of resilience. Doctoral Dissertation. The University of Texas at Arlington.

Samuels, W.E., \& Woo, Ada. (2009). Creation and initial validation of an instrument to academic resilience. Research Report. American Educational Research Association.

Santrock, J.W. (2002). Adolescene. Boston: McGraw Hill.

Sarafino, E.P. (1994). Health psychology: Biopsychosocial interaction $2^{\text {nd }}$ edition. New York: John Wiley \& Sons, Inc.

Sarason, I.G., Levine, H.M., Bahsam, R.B., \& Sarason, B.R. (1983). Assessing social support: the social support quetionnare. Journal of Personality and Social Psychology, (52), 813-832.

Sarason, I.G., Sarason, B.R., Shearin, E.N \& Pierce, G.R. (1987). A brief measure of social support: practical and the theoretical implications. Journal of Social and Personal Relationship, (4), 497-510.

Sarwono, S.W. (2012). Psikologi remaja. Jakarta: RajaGrafindo Persada.

Schoon, I. (2006). Risk and resilience: Adaptations in changing times. Review by Foster, E Michael. Journal of Marriage and Family, 68 (5), 1383-1384.

Sheridan \& Radmacher. 1992. Health Psychology: Challenging The Biomedical Model. Singapore: John Wiley \& Sons, Inc. 
Skinner, E.A., Kindermann, T. A., \& Furrer, C. J. (2008). A Motivational Perspective on Engagement and Disaffection: Conceptualization and Assessment of Children"s Behavioral and Emotional Participation in Academic Activities in the Classroom. Journal of Educational and Psychological Measurement, 20 (10), 1-33.

Smet, B. (1994). Psikologi kesehatan. Jakarta: PT. Gramedia Widiasarana Indonesia.

Speight, N.P. (2009). The relationship between self-efficacy, resilience and academic achievement among african-american urban adolescent students. Doctoral Dissertation. Washington .D.C: Howard University.

Yusuf, S. (2004). Psikologi perkembangan anak dan remaja. Bandung: Remaja Rosdakarya.

Taylor, S.E. (2006). Health Psychology $6^{\text {th }}$ edition. New York: Mc.Graw Hill.

Taylor, J., \& Nelms, L. (2006). Life chances at 15: Resilience and engagement. Research Report. Australia: Brotherhood of St.Laurence.

Thompson, B. (2004). Explanatory and confirmatory factor analysis. Washington D.C: American Psychological Associaton.

Tugade, M.M. \& Fredrikson, B.L. (2004). Resilient individuals use positive emotions to bounce back from negative emotional experiences. Journal of Personality and Social Psychology, 86 (2), 320-333.

Umar, J., dkk. (2012). Panduan Penulisan Skripsi dengan Pendekatan Kuantitatif. Jakarta: Fakultas Psikologi UIN Syarif Hidayatullah Jakarta.

Umar, J. (2013). Materi Pelatihan Analisis Faktor. Jakarta: Fakultas Psikologi UIN Syarif Hidayatullah.

United Nation Educational, Scientific and Cultural Organization. (2012). Education for all global monitoring report. Research Report. France.

Waxman, H.C., Gray J.P. \& Padron. Y.N. (2003). Review of research on educational resilience. Research Report. California: Center for Researh on Education Diversity and Excellence.

Werner, E.E. (2005). Chapter one: Resilience research: past, present and future. Dalam R.D Peters, B. Leadbeater \& R.J. McMahon (Eds.). Resilience in children, families and community: Linking context to Practice and Policy (3-11). New York: Kluwer Academic/Plenum Publisher.

Williams, J.M. (2011). Home, school and community factors that contribute to the educational resilience of urban, african american high school graduates from low-income, single-parent families. Doctoral dissertation. University of Iowa.

Willms, J.D. (2003). Student engagement at school: A sense of belonging and participation. Result Report from PISA 2000. Organisation for Economic Co-operation and Development.

Zimet, G.D. \& Canty-Mitchell. (2000). Psychometric properties of the multidimensional scale of perceived social support in urban adolescents. American Journal of Community Psychology, 28 (3), 391-401. 
